\title{
Macro-, micromorphological characters and DNA fingerprinting markers on three Ruprechtia species (Polygonaceae) in Egypt
}

\author{
Mohamed E. Tantawy \\ Botany Dept., Faculty of Science, \\ Ain Shams University-Egypt. \\ e. mail : mtantawy @ asunet. shams. eun.eg
}

and

\author{
Maher M. Shehata \\ Botany Dept., Faculty of Science, \\ Ain Shams University-Egypt.
}

\begin{abstract}
Tantawy M.E. \& Shehata M.M. 2001. Macro-, micromorphological characters and DNA fingerprinting markers on three Ruprechtia species (Polygonaceae) in Egypt. Taeckholmia 21(1):1-13 .

Macro-,micromorphological characters and DNA fingerprinting markers have been used to differentiate the three Ruprechtia C. A. Meyer species growing in Egypt (R. exelsa, R. polystachya, and R. salicifolia). Interestingly, the macro- and micromorphological criteria of the vegetative organs showed no fundamental characters to discriminate between the three examined species. However, the data obtained from the seed coat surface (using LM and SEM) revealed some variability among the tested species. Seed coat surface was colliculate in $(R$. excelsa), pusticulate in (R. polystachya) and reticulate-scalariform in $R$. salicifolia. Accordingly, the seed coat surface can be used as a fundamental criterion to discriminate between the species of this study. The RAPDPCR electrophoretic profile, showed unique RAPD markers some of which were species-specific. Speciesspecific markers were recorded by using primers OPA-01, OPA-02 and OPA-05 respectively. Two RAPD markers specific to R. polystachya and $R$. salicifolia were recorded. The two markers for the former species have a molecular size of 1800 and $2600 \mathrm{bp}$ using primer OPA-01. While those specific to the latter species have a molecular size of 300 and 400 bp using primers OPA-02. For $R$. excelsa, one specific RAPD marker was recorded, it has a molecular size $800 \mathrm{bp}$ using primer OPA-05. The RAPD markers may be considered as valid criteria to discriminate between the three Ruprechtia species used in this investigation. However, the similarity in the banding profile of RAPD-PCR and the morphological criteria justify the maintenance of the three species in the same genus.
\end{abstract}

Key words: Ruprechtia, Polygonaceae, morphology, seed coat surface, DNA fingerprinting.

\section{Introduction}

Ruprechtia C. A. Meyer (Polygonaceae; Polygonoideae, Tribe: Triplareae), was established by Meyer (1840) as a new world genus on the basis of Triplaris ramiflora Jacq. Meisner (1855), added that the fruiting perianth tube is never more than two thirds the length of the achene which is pyramidal trisulcate. The entry for this genus in index Nominum Genericorum (Farr et al., 1979), indicates that $R$. salicifolia as a lectotype following Roberty and Vautier (1964), but ignoring the earlier lectotypification by Cocucci (1961). Some species of the genus are based on scanty material, and hence their 
range of variations as well as their distributional ranges are not well established (Aymard et al., 1999).

The species of Ruprechtia show a range of variation in fruiting perianth characters from non-connate to partly connate. However, this character was not valid as a criterion for generic delimitation (Brandbyge, 1989). During a taxonomic study of the neotropical genus Triplaris Loefl. Ex L. Brandbyge and Øllgaard (1984), realized that the generic delimitation between Triplaris and Ruprechtia had been confused in earlier literature and was in need of a new evaluation.

Ruprechtia is a genus of small trees or shrubs from neotropical dry and riverine forests. Brandbyge and Øllgaard (1984) and Brandbyge (1984 and 1986), reported that this genus has been closely allied with Triplaris, but differs in its two-or three-pistillate partial inflorescence, a basal pedicel-like extension of the perianth tube in fruit, and pedicellate male flowers with perianth segments connate for less than a third of their length. It also typically has fewer pairs of secondary leaf veins (less than 12) than Triplaris, smaller leaves, and achenes loosely enclosed within the fruiting perianth, the inflorescences are mostly axillary. Praglowski and Punt (1973); Nowicke and Skvarla (1977) and Hong (1995), showed that pollen grains have perforate-rugose surfaces which appear slightly spinulose in some species. Brandbyge and Øllgaard (1984), studied the inflorescence structure to make generic delimitation of Triplaris and Ruprechtia. Many studies on Ruprechtia as a new genus has been carried out. To cite but a few one can refer to the work of Brandbyge (1990); Barrios (1995); Barrios et al. (1995); Rivera and Lenton (1999) and Ortiz and Paiva (1999).

Traditionally, markers based on morphological and anatomical differences have been used to demonstrate the genetic variability. However, the advent of molecular biology techniques has provided more powerful markers that allow the visualization of polymorphism directly at the DNA level. The most widely used molecular marker available nowadays is RAPD - PCR (randomly amplified polymorphic DNA-polymerase chain reaction) technique (Williams et al., 1990).

RAPD-PCR has been a very exciting development in molecular biology. RAPD's are genetic markers resulting from PCR amplification of DNA segments recognized by random primers of arbitrary nucleotide sequences (Williams et al., 1990). RAPD-PCR offers several advantages over other methods used for studying variability, because it is not limited to a single locus but theoretically detects polymorphism across the whole genome. RAPD markers detect polymorphism in regions of the genome containing repeated sequences (Michelmore et al., 1991). The differential amplification may be due to sequence differences in the priming sites (Williams et al., 1990; 1993 and Caetano-Anolles et al., 1991) or due to point mutation which allow or abolish primer binding (Hedrick, 1992). Thus, the polymorphisms are essentially due to differences in frequency and distribution of the priming sites.

In taxonomy and systematics, species-specific RAPD markers could be a valuable tool for species verification and in establishing the status of organisms of controversial systematic position (Williams et al., 1990). Halword et al. (1992), using the polymerase chain reaction to detect the genteic polymorphism in cultivated Arachis hypogea L. and related wild species. Foolad et al. (1993), used the RAPD technique for the isolation of molecular markers for Lycopersicum esculentum Mill.

RAPD markers have also demonstrated genetic differences among different species of Glycine (Williams et al., 1993), Allium (Wilkie et al., 1993) and Caesalpinia 
echinata L. (Cardoso et al., 1998). Szmidt et al. (1996), reported that the RAPD markers are inherited primarily as dominants and the banding patterns cannot be analysed routinely by the gene diversity statistics. Rossetto et al. (1997), used RAPD analysis to demonstrate the additive inheritance of DNA markers of Eucalyptus rudis Endl., E. drummondii Benth. and the putative parent species in E. gramiticola. They used nine arbitrary primers to determine the genetic RAPD markers for these different species of Eucalyptus. They found that 9 mer primers consistently produce a greater number of markers than 10 mer primers. They also found that the pattern of similarities and differences between species showed broad agreement across primers, but that overall level of similarity varied between primers. Therefore, The choice of primers is of major importance for the discriminatory power of the technique.

Primers usually do not have the same amplification efficiency. Some primers are more efficient in amplifying DNA template than others. This depends on the sequence of primers, its length and GC content (Williams et al., 1990). Kantanen et al. (1995), found that some primers fail to amplify DNA while others produce complex banding pattern. Caetno-Anolles et al. (1991), reported that the different primers have different performances for the evaluation of genetic polymorphism.

The main purpose of the present study is to use new evidence derived from macro- and micromorphological criteria as well as DNA fingerprinting to detect the morphological and genetic variability among three Ruprechtia species growing in Egypt. This study has two objectives : a) To evaluate the morphological criteria of the Ruprechtia species, and their sharing in the descrimination between them. b) To reveal genetic variations among the three species of Ruprechtia using RAPD markers, and how can these markers affect the relationships among the three species.

\section{Materials and Methods}

Three species of Ruprechtia were collected from Orman Botanic Garden (Ruprechtia polystachya Griseb and $R$. salicifolia Brass), and Zohria Botanic Garden (R. excelsa Griseb), Cairo, Egypt.

\section{I-Methods for macro- and micromorphological investigations:}

Sections for micromorphological study of the vegetative organs (stem and blade) were made according to the methods described in Johansen (1940). For SEM, the seeds were dried and fixed to specimen stubs with an adhesive and placed on the revolving discs of Joel fine coat ion sputter (Joel, JFC 1100) where each seed was uniformly coated with 20$30 \mathrm{~nm}$ thick gold. These specimen stubs were then fixed to the specimen holder of scanning electron microscope (Joel JSM 350) maintained at accelerating potential of 15 $\mathrm{KV}$., and photomicrographs were taken at different magnifications. The terms used for describing the seed coat patterns have been adopted according to Stearn (1966).

\section{II-Methods for molecular investigations:}

Young leaves were collected and 20 samples from each species were kept in an ice chest before being brought back to the laboratory where samples were stored in a $-70^{\circ} \mathrm{C}$ freezer until DNA extraction. 


\section{a) DNA extraction and quantification}

DNA was extracted using the CTAB method of Doyle and Doyle (1987). From each species, $50 \mathrm{mg}$ of fresh leaf tissue was powdered in liquid nitrogen and $0.8 \mathrm{ml}$ of CTAB extraction buffer were added and DNA was precipitated with isopropanol, washed in $70 \%$ ethanol, and dissolved in deionized water. The DNA concentration was measured using a Hoefer TKO 100 fluorometer with Hoechst dye solution.

\section{b) Amplification of RAPD markers}

Five 10 mer oligonucleotide primers of arbitrary sequences obtained from the Operon-A primer kit (Operon Tech. Inc., USA), were used in this study. The sequences of these primers and their GC ratio are shown in table 1 . The polymerase chain reactions were carried out in $50 \mu \mathrm{L}$ total reaction volume contaning $100 \eta \mathrm{g}$ of genomic DNA template, 10 pmol primer, $200 \mu \mathrm{M}$, each of dATP, dCTP, dTTP and dGTP, 50mM KCl, 10mM Tris-Cl ( $\mathrm{pH} 8.0$ ), $3 \mathrm{mM} \mathrm{MgCl}_{2}, 0.01 \%$ gelatin and 2 units of Taq polymerase. Each reaction mixture was overlaid with a drop of mineral oil to avoid evaporation and condensation of samples on the walls and tips of the tubes and incubated in Perkin Elmer Cetus thermal cycler programmed as follows: an initial strands separation (hot start ) at $94^{\circ} \mathrm{C}$ ( $\left.6 \mathrm{~min}\right)$ followed by 40 cycles with the following temperature profile [ $94^{\circ} \mathrm{C}(1 \mathrm{~min})$; $36^{\circ} \mathrm{C}(2 \mathrm{~min})$ and $\left.72^{\circ} \mathrm{C}(3 \mathrm{~min})\right]$ and a final post-extension at $72^{\circ} \mathrm{C}(7 \mathrm{~min})$. Amplification products were analysed by electrophoresis in $1.8 \%$ agarose gels and stained with ethidium bromide. A molecular size marker (1kb ladder, Promega ) was used in each run as a standard marker. The results were documented by photography using polaroid ${ }^{\mathrm{R}}$ Camera. Gel analysis was performed in a GDS model UVP's GDS 8000 California 91786 USA to analyse the band pattern.

Table 1: The sequence and GC ratio of the five decamer arbitrary primers used for RAPDPCR analysis

\begin{tabular}{|l|l|l|}
\hline Primer & Sequence $\left(5{ }^{\prime}\right.$ to $\left.3{ }^{`}\right)$ & $\%$ GC \\
\hline OPA- 01 & CAGGCCCTTC & 70 \\
OPA- 02 & TGCCGAGCTC & 70 \\
OPA-03 & AGTCAGCCAC & 60 \\
OPA- 04 & AATCGGG CTG & 60 \\
OPA- 05 & AGGGGTCTTG & 60 \\
\hline
\end{tabular}

\section{c) - Analysis of RAPD data}

RAPD bands were treated as either present or absent without considering banding density. For estimating genetic distance among the tested samples; each DNA band was treated as a unit character and each sample was scored for the presence or absence of band respectively. Genetic similarity (GS) was analysed using the equation of Jaccard (1908): $\mathrm{GS}=2 \mathrm{~N}_{\mathrm{ab}} /\left(\mathrm{N}_{\mathrm{a}}+\mathrm{N}_{\mathrm{b}}\right)$, where $\mathrm{N}_{\mathrm{ab}}$ is the number of shared fragments between plants a and $\mathrm{b} ; \mathrm{N}_{\mathrm{a}}$ is the number of scored fragments of plant $\mathrm{a}$ and $\mathrm{N}_{\mathrm{b}}$ is the number of scored fragments of plant $b$. 


\section{Results and discussion}

\section{I - Morphological criteria}

The macro-and micromorphological characters of the vegetative organs and the features of seed coat surface of three Ruprechtia species are described as follows:

\section{1-Ruprechtia excelsa Griseb}

\section{Exomorphology}

Woody tree with simple lanceolate glabrous leaves. The latter are grey to greyish brown. Young leaves are golden to brown. Staminate inflorescence not available. Pistillate inflorescence axillary unbranched to slightly branched, axis up to $13 \mathrm{~cm}$ long, bracts long broadly ovate-triangular, densely appressed pilose outside, glabrous inside. Perianth six units persistent at fruiting. Staminodes mostly absent, but occasionally present as very short projections from the disc. Achenes trisulcate, pale brown to brown, whitish pilose, especially dense towards apex, style and stigma very short. Ovule one on basal placentation.

\section{Stem microcharacters (Fig. 1a)}

Stem terete in cross section. Epidermal cells tangentially elongated. Subepidermal cork cells of two-three layers present. Cortex of angular collenchyma and polyhedral parenchyma. The vascular tissue show a continuous cylinder outlined by a ring of highly thickened fibers. Uniseriate rays in fascicular and interfascicular regions was detected. Druses are numerous in both cortex and pith .

\section{Blade microcharacters (Fig. 1b)}

Epidermis radially-tangentially elongated. Mechanical tissue at the abaxial and adaxial sides of the mid vein region is angular collenchyma. Mesophyll is of dorsiventral type. The vascular supply is of group of vascular bundles arranged in a more or less compressed ring, each is outlined by a rather prominent fiberous sheath.

\section{Seed coat scan (Fig. 1c)}

Seeds oblong ovate, brown in colour, $3.5 \times 1.5 \mathrm{~mm}$ in dimensions. The seed coat surface is colliculate with rounded broad elevations closely spaced covering the seed coat. The periclinal walls are thick, slightly convex and smooth. The anticlinal walls are slightly wavy, thick and deeply depressed.

\section{2- Ruperchtia polystachya Griseb}

\section{Exomorphology}

Woody glabrescent tree. Leaves ovate or oblong ovate with prominent veins. Pistillate inflorescence raceme-like with pink green to violet or mauve colour. Stamimate inflorescence not available . Flowers bracteate with long pedicels. Perianth 3-6 parts, long persistent at fruiting stage. 


\section{Stem and blade microcharacters (Figs. 1 d \& e)}

The micromorphological characters of stem and blade of Ruprechtia polystachya are similar to those of $R$. excelsa except, the presence of some fiber patchs at the end of xylem toward the pith of the stem.

\section{Seed coat scan (Fig. 1 f)}

Seeds oblong ovate or ovate, three-sided, brown in colour. Seeds are $3.0 \times 1.3 \mathrm{~mm}$ in dimensions. Seed surface is pusticulate i.e with small broad slight elevations not so high or abundant as on a colliculate surface, and not having as abrupt elevations as a minutely tuberculate surface. The periclinal walls are slightly convex, smooth and striated. The anticlinal walls are thick and shallow depressed.

\section{3- Ruprechtia salicifolia Brass}

\section{Exomorphology}

Woody tree or shrubs. Leaves lanceolate with entire margin and acute apices. The staminate inflorescence axillary, or terminal branched, each flower subtended by a scaly bract. Perianth six units in two whorls. Stamens 8-9 in two whorls with long filaments. Pistillate flowers are small, green, and similar to the inflorescence of $R$.. excelsa.

\section{Stem and blade microcharaters (Figs. 1 g \& h)}

Similar to the anatomical structures of $R$. excelsa.

\section{Seed coat scan. (Fig. 1 i)}

Seeds more or less flattened ovoid, brown in colour, $4.0 \times 2.0 \mathrm{~mm}$ in dimensions. The seed surface is reticulate-scalariform (i.e. with raised network of narrow and sharply angled lines frequently presenting a geometric appearance with several small fairly regular cross band markings suggesting the steps of a ladder). The periclinal walls are striated and smooth. The seed coat surface is covered by cutinized depositions that give definite reticulation patterns. The depositions slightly wavy so that they may mask the boundary of the anticlinal walls.

The macro-and micromorphological criteria of the vegetative organs of the three Ruprechtia species are fundamentally similar. This view is in accordance with the interpretation of Tantawy (1989) in that the macro-and micromorphological characters of the vegetative organs are not obviously significant to make separation between the above Ruprechtia species.

From the foregoing data, it is clear that the seed coat surface is colliculate in $R$. excelsa, pusticulate in $R$. polystachya and reticulate-scalariform in $R$. salicifolia. These differences agree with the work of Musil (1948), Corner (1976), Tantawy and Rabie (2000) and Tantawy (2000) in that the variations in seed coat patterns may be provied basic criteria for the identification and classification of taxa and in establishing the phylogenetic relationship between them. Therefore, the seed coat surface variations in the present study were considered as fundamental characters to discriminate between the three Ruprechtia species. 


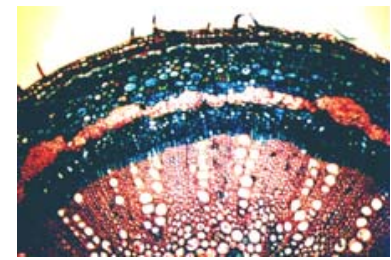

a

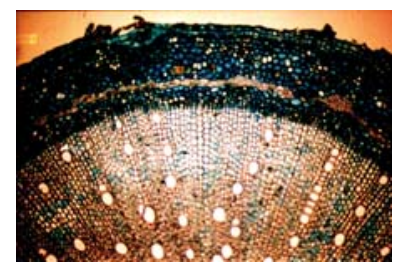

d

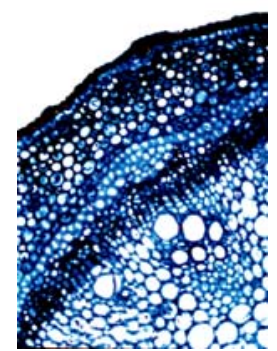

g

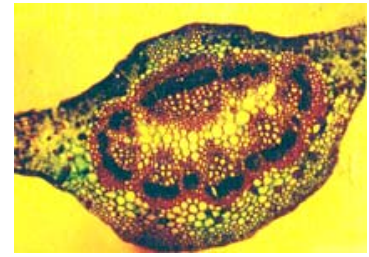

b
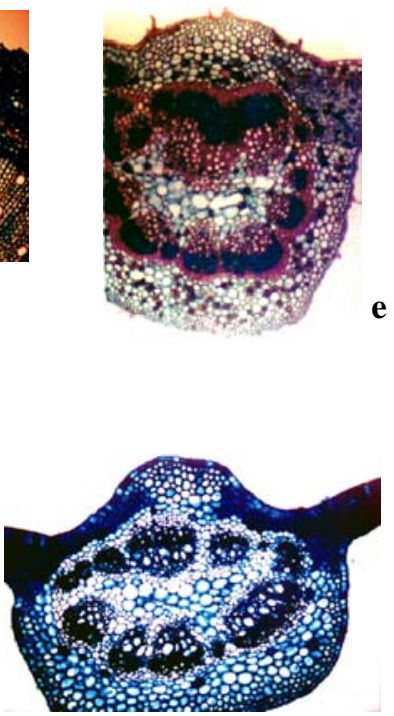

h

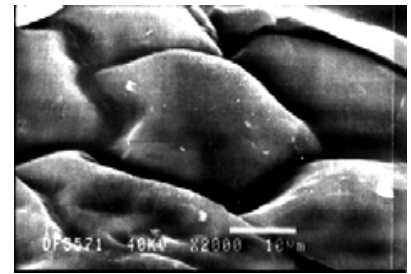

c

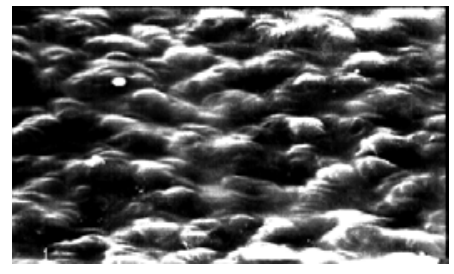

f

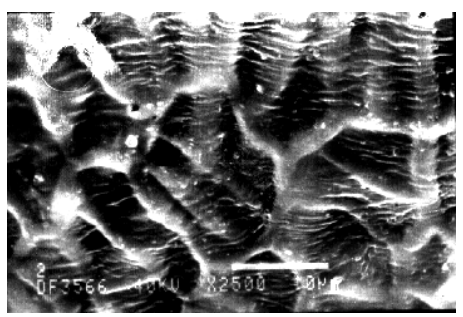

i

Fig. 1. (a-c) Ruprechtia excelsa (stem, blade and seed surface); (d-f) R. polystachya and (g-i) R. salicifolia

\section{II- Genetic diversity as revealed by RAPD's}

The DNA of the Ruprechtia species were amplified using five decamer primers to detect the genetic variability. Each of the five primers successfully directed the amplification of a genome-specific fingerprint of DNA fragments. All amplifications were found to be reproducible when repeated at different times under the same condition of amplification. After PCR amplification, interspecific diversity was evaluated between these species.

The five primers of arbitrary sequences used in our investigation generated 26, 25 and 26 fragments in $R$. excelsa, $R$. polystachya and $R$. salicifolia respectively (Tables 2 and 3 ). The total number is 77 bands, 20 were polymorphic fragments representing a polymorphism of $25.97 \%$. In addition to these fragments, a group of bands with low molar ratio (weaker intensity of stain) appeared occasionally but were less reproducible. The 
RAPD-PCR products for the three Ruprechtia species obtained using five decamer primers are shown in Plate II; Figs. 1-5.

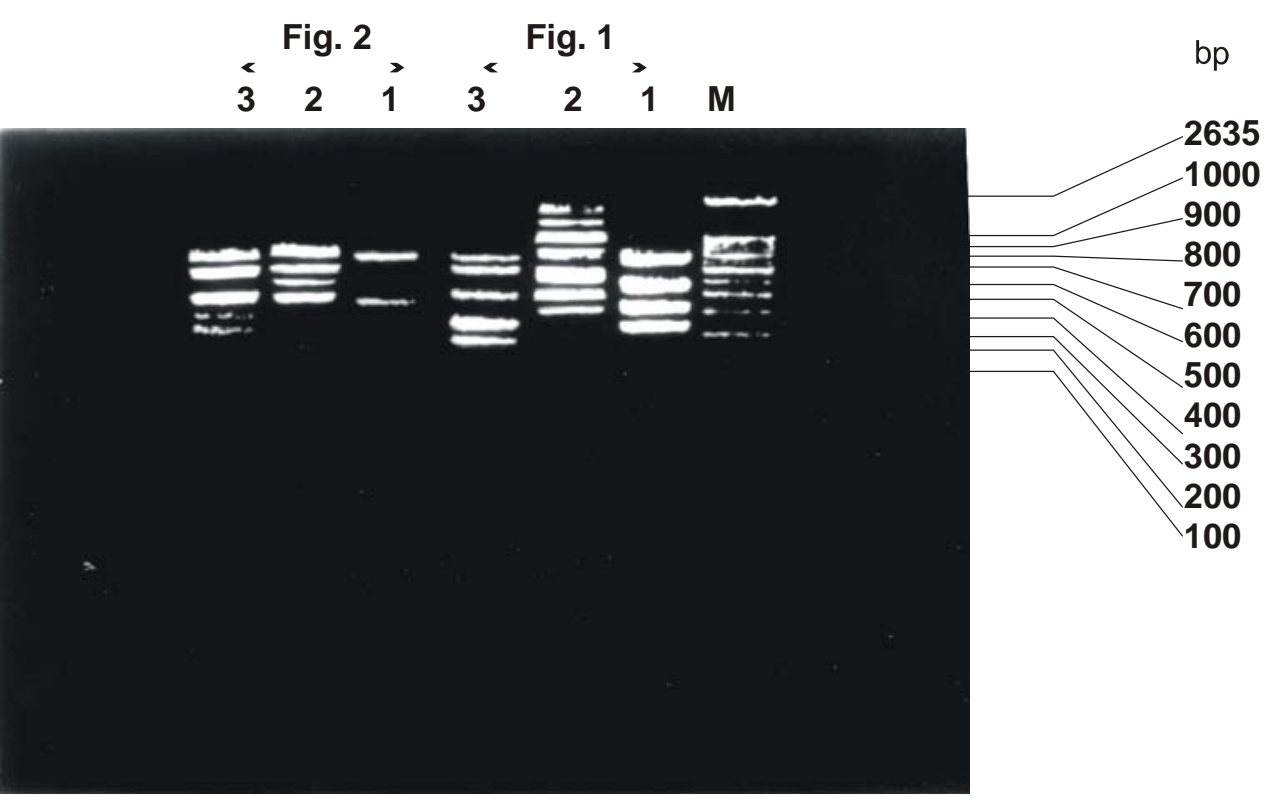

Fig. 5

$\begin{array}{llll}3 & 2 & 1 & M\end{array}$

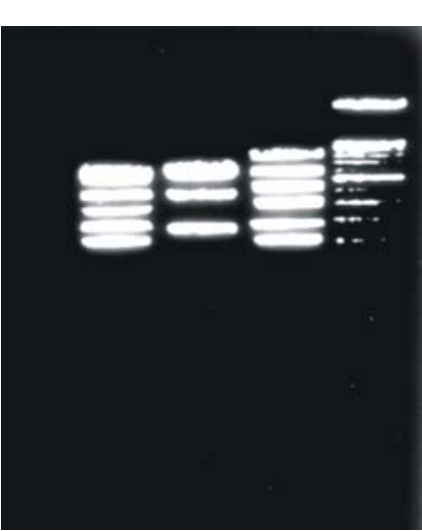

Fig. 4

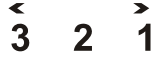

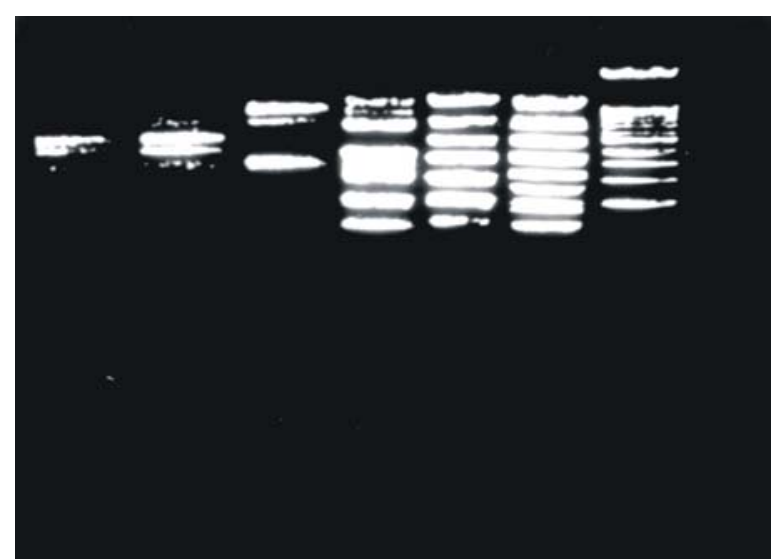

Plate II (Figs. 1-5): RAPD-PCR markers detected in three Ruprechtia species (Lane M: DNA molecular size marker, Lane 1: $R$. excelsa, Lane 2: $R$. polystachya and Lane 3: $R$. salicifolia) using five decamer primers (Fig. 1: OPA-01, Fig. 2: OPA02, Fig. 3: OPA-03, Fig. OPA-04, and Fig. 5: OPA-05). 
From tables 2, 3 and figure (1), it is clear that, the five primers produced multiple-band profiles and the number of amplified fragments ranged from 3 to 8, while the number of polymorphic fragments ranged from 2 to 8 .

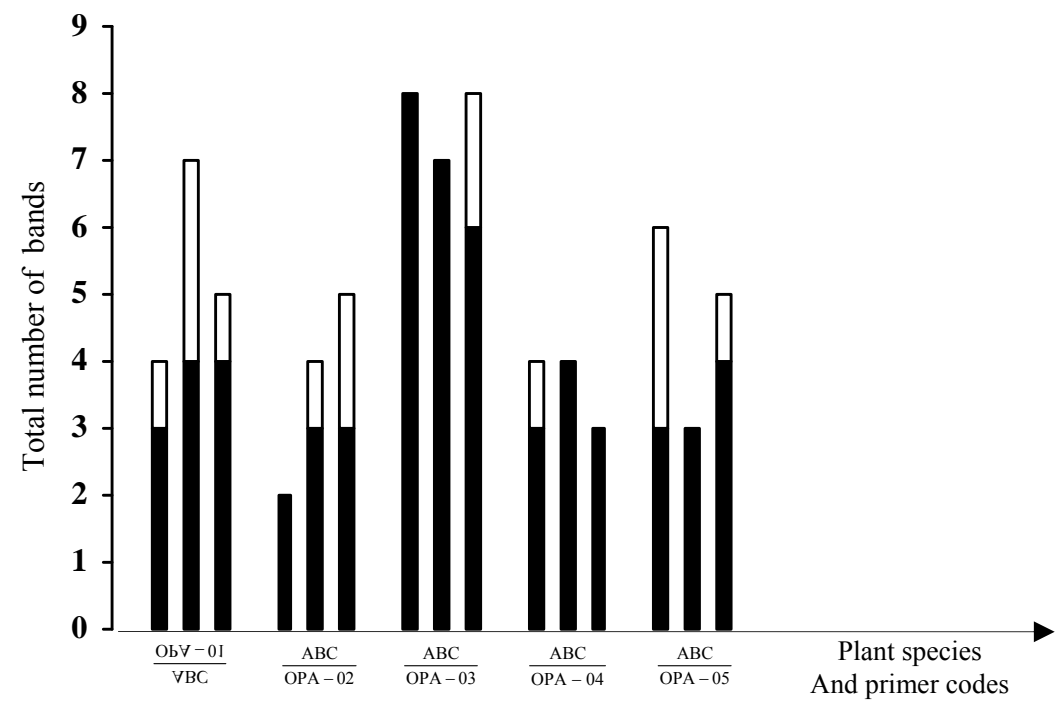

Figure (1): Distribution of polymorphic $\square$ and monomorphic $\mathbf{\square}$ DNA fragments generated in three Ruprechtia species using five decamer primers. A: $R$. excelsa; B: $R$. polystachya; C: R. salicifolia.

Table (2): The total number of RAPD-PCR fragments, distribution of monomorphic and polymorphic bands and similarity coefficients generated by five decamer arbitrary primers in three Ruprechtia species. A: Ruprechtia excelsa ; B: R. polystachya; C: R. salicifolia

\begin{tabular}{|c|c|c|c|c|c|c|c|c|c|c|c|c|c|}
\hline \multirow{2}{*}{$\begin{array}{l}\text { Primer } \\
\text { codes }\end{array}$} & \multicolumn{4}{|c|}{ RAPD fragments } & \multicolumn{3}{|c|}{$\begin{array}{c}\text { Monomorphic } \\
\text { fragments }\end{array}$} & \multicolumn{3}{|c|}{$\begin{array}{c}\text { Polymorphic } \\
\text { fragments }\end{array}$} & \multicolumn{3}{|c|}{ Similarity coefficients } \\
\hline & $\mathrm{A}$ & $\mathrm{B}$ & $\mathrm{C}$ & Total & $\mathrm{A}$ & $\mathrm{B}$ & $\mathrm{C}$ & $\mathrm{A} / \mathrm{B}$ & $\mathrm{A} / \mathrm{C}$ & $\mathrm{B} / \mathrm{C}$ & $\mathrm{A} / \mathrm{B}$ & $\mathrm{A} / \mathrm{C}$ & $\mathrm{B} / \mathrm{C}$ \\
\hline OPA - 01 & 4 & 7 & 5 & 16 & 3 & 4 & 4 & 5 & 5 & 6 & 54.54 & 66.66 & 50.00 \\
\hline OPA - 02 & 2 & 4 & 5 & 11 & 2 & 3 & 3 & 2 & 3 & 3 & 66.66 & 57.14 & 44.44 \\
\hline OPA - 03 & 8 & 7 & 8 & 23 & 8 & 7 & 6 & 1 & 4 & 3 & 93.33 & 75.00 & 80.00 \\
\hline OPA - 04 & 4 & 4 & 3 & 11 & 3 & 4 & 3 & 2 & 3 & 1 & 75.00 & 57.14 & 85.71 \\
\hline OPA - 05 & 6 & 3 & 5 & 14 & 3 & 3 & 4 & 3 & 1 & 3 & 66.66 & 72.72 & 75.00 \\
\hline Total & 26 & 25 & 26 & 77 & 16 & 21 & 20 & 13 & 16 & 16 & $\begin{array}{l}\text { Mean } \\
71.24\end{array}$ & $\begin{array}{l}\text { Mean } \\
65.73\end{array}$ & $\begin{array}{l}\text { Mean } \\
67.03\end{array}$ \\
\hline
\end{tabular}


Table (3): Molecular size in base pairs of amplified DNA fragments produced by five decamer primers in three Ruprechtia species. A: R. excelsa; B: R. polystachya; C: $R$. salicifolia; $(+)$ : presence of band and (-): absence of band

\begin{tabular}{|c|c|c|c|c|c|c|c|c|c|c|c|c|c|c|c|}
\hline \multirow{2}{*}{$\begin{array}{c}\text { Molecular } \\
\text { size (bp) }\end{array}$} & \multicolumn{3}{|c|}{ OPA-01 } & \multicolumn{3}{|c|}{ OPA-02 } & \multicolumn{3}{c|}{ OPA-03 } & \multicolumn{3}{c|}{ OPA-04 } & \multicolumn{3}{c|}{ OPA-05 } \\
\cline { 2 - 17 } & A & B & C & A & B & C & A & B & C & A & B & C & A & B & C \\
\hline 150 & - & - & - & - & - & - & + & + & + & - & - & - & - & - & - \\
\hline 200 & - & - & + & - & - & - & + & + & + & - & - & - & - & - & - \\
\hline 300 & + & - & + & - & - & + & - & - & - & - & - & - & + & - & + \\
\hline 400 & + & + & - & - & - & + & + & - & - & - & - & - & + & + & + \\
\hline 500 & - & + & + & + & + & + & + & + & + & + & + & + & + & - & + \\
\hline 550 & - & - & - & - & - & - & - & - & + & - & - & - & - & + & + \\
\hline 600 & + & - & - & - & + & - & + & + & + & + & + & - & + & - & - \\
\hline 700 & - & + & + & - & + & + & + & + & - & + & + & + & + & + & + \\
\hline 800 & + & + & + & + & + & + & + & + & + & + & + & - & + & - & - \\
\hline 1000 & - & + & - & - & - & - & - & - & + & + & - & - & - & - & - \\
\hline 1100 & - & - & - & - & - & - & + & + & + & - & - & - & - & - & - \\
\hline 1800 & - & + & - & - & - & - & - & - & - & - & - & - & - & - & - \\
\hline 2600 & - & + & - & - & - & - & - & - & - & - & - & - & - & - & - \\
\hline
\end{tabular}

The highest degree of similarity was recorded between $R$. excelsa and $R$. polystachya $(71.24 \%)$ and the lowest degree was recorded between $R$. excelsa and $R$. salicifolia $(65.73 \%)$ using primer OPA-03 (table2). The highest degree of polymorphism between the three investigated species was obtained (using primers OPA-01, OPA-02 and OPA-05). The pattern obtained using primer OPA- 03 was identical in the three species. While the patterns obtained using primers OPA-01, OPA-02 and OPA-05 are speciesspecific. The latter primers may be used as an indicator for obtaining genetic markers specific for $R$. excelsa, R. polystachya and R. salicifolia. Two RAPD markers specific to $R$. polystachya and $R$. salicifolia were recorded. The two markers for the former species were at molecular sizes 1800 and 2600 bp using primer OPA-01. While those specific to the latter species were at molecular sizes 300 and $400 \mathrm{bp}$ using primers OPA-02. For $R$. excelsa, one specific RAPD marker was recorded at a molecular size $800 \mathrm{bp}$ using primer OPA-05. Kazan et al. (1993), found that the RAPD markers generated from 20 cultivars and accessions of Stylosanthes could assess the level of DNA variation. They reported that relatively low levels of polymorphism were found within each species, while polymorphism between species were much higher. Our results are in agreement with those obtained by many investigators (Virk et al., 1995; Welsh et al. , 1995 ; Yang et al., 1998 ; Wen and Hsiao , 1999 and Esselaman et al., 2000) using RAPD markers for identification and differentiation of different plant species and cultivars. They reported that the use of a specific combination of template DNA and primer gave reproducible results. 


\section{The final conclusions of the current study are that:}

a- The macro-and micromorphological criteria of the vegetative organs (stem and blade) are not obviously significant to make a descrimination between the three Ruprechtia species under investigation.

b- The results obtained from the seed coat surface as well as the aspect of the periclinal and anticlinal walls are of highly significance to make this descrimination. The seed coat surface is colliculate, in $R$. excelsa, pusticulate in $R$. polystachya while in $R$. salicifolia, the surface is reticulate-scalariform.

c- The data extracted from RAPD's polymorphism indicate that; each species of Ruprechtia has a unique array of RAPD loci. Some of these bands are speciesspecific (obtained by using primers OPA-01, OPA-02 and OPA-05) primers. These primers may be used to reveal molecular markers for the descrimination and maintenance of three Ruprechtia species.

d- The seed coat surface variations and RAPD markers diversity justify the separation between the Ruprechtia species .

e- In the light of the evidences given above, we conclude high degree of similarity between $R$. excelsa and $R$. polystachya $(71.24 \%)$ and low degree between $R$. excelsa and $R$. salicifolia $(65.73 \%)$ using primer OPA-03. Therefore, it may be justified to maintain the three species of Ruprechtia.

\section{Acknowledgments}

We thank Drs. A. S. Al-Nowaihi and S. F. Khalifa, Profs. of plant taxonomy and flora and Dr. S.E. El-Khodary, Prof. of cytogenetics for their continuous encouragement.

\section{References}

Aymard C., Gerarado A. \& Berry-Paul E. 1999. A new species of Ruprechtia (Polygonaceae) from the Venezuelan Guayana. Novon, 9(3): 313-314.

Barrios E. 1995. Agroforestry on tropical floodplains: indigenous know-how from Venzuela. Agroforestry-Today, 7(1):13-15.

Barrios E., Herrera R. \& Valles J. L. 1995. Tropical floodplain agroforestry system in mid - Orinoco River basin, Venzuela. Agroforestry-Systems, 28:143-157.

Brandbyge J. 1984. Three new species of the genus Triplaris (Polygonaceae). - Nord. J. Bot., 4:761-764.

Brandbyge J. 1986. A rivision of the genus Triplaris ( Polygonaceae ). Nord. J. Bot., 6:545-570.

Brandbyge J. 1989. Notes on the genus Ruprechtia (Polygonaceae). Nord . J. Bot., 9:5761.

Brandbyge J. 1990. Woody Polygonaceae from Brazil: new species and a new interpretation. Nord. J . Bot.,10 (2):155-160.

Brandbyge J. \& Øllgaard. 1984. Inflorescence structure and generic delimitation of Triplaris and Ruprechtia ( Polygonaceae ). Nord . J. Bot., 4:765-769.

Caetan -Anolles G., Bassam B. J. \& Gresheff P. M. 1991. fingerprinting using very short arbitrary primers. Biotech., 9:553-557. 
Cardoso M. A., Provan J., Powell W., Ferreira P.C.G. \& Oliveira D.E. 1998. High genetic differentiation among remnant populations of the endangered Caesalpinia echinata L. (Leguminosae-Caesalpinioideae). Mol. Ecol., 7:601-608.

Cocucci A. E. 1961. Revision del genero Ruprechtia (Polygonaceae). Kurtziana 1:217269.

Corner E. S. H. 1976. “ The seeds of Dicotyledons “ I. Cambridge, U. K.

Doyle J. J. \& Doyle J. L. 1987. A rapid DNA isolation procedure for small quantities of fresh leaf tissue. Phytochem. Bull., 19:11-15.

Esselman E. J., Crawford D. J., Brauner S., Stuessy T. F., Anderson G. J. \& Silva M. 2000. RAPD marker diversity within and divergence among species of Dendroseris. Amer. J. Bot., 87: 519.

Farr E. R., Leussink J. A. \& Stafleu F. 1979. Index Nominum Genericorum (Plantarum) Vol. III - Regnum Veg. Vol. 102.

Foolad M. R., Jones R. A. \& Rodriguez R. L. 1993. RAPD markers for constructing intraspecific tomato genetic maps. Plant Cell Res., 12: 293 - 297.

Halword T., Stalker T., Larue E. \& Kochent G. 1992. Use of single-primer DNA amplifications in genetic studies of peanut (Arachis hypogaea L.). Plant Mol. Biol., 18: 315 - 325 .

Hedrick P. 1992. Shooting the RAPDs. Nature, 355:679-680.

Hong S.P. 1995. Pollen morphology of Parapteropyrum and some putatively related genera (Polygonaceae, Atraphaxideae). Grana, 153-159.

Jaccard P. 1908. Novelles recgerches sur la distribution florale. Bull. Soc. Vaud. Sci. Nat., 44: $223-270$.

Johansen D. A. 1940. Plant Microtechnique, New York, Book Company p. 523.

Kantanen J., Vilkki J., Elo K. \& Maki - Tanila A. 1995. Random amplified polymorphic DNA in cattle and sheep: application for detecting genetic variation. Anim. Genet. , 26: 315 - 320 .

Kazan K., Manners J. M. \& Cameron D. F. 1993. Genetic variation in agronomically important species of Stylosanthes, determimed using random amplified polymorphic DNA marker. Theor. Appl. Genet. , 85:882-888 .

Meisner C . F. 1855. Polygonaceae.-In: Martius, C. F. P. Flora Brasiliensis 5(1), Munich, pp. $1-59$.

Meyer C. A. 1840. Einige Bemerkungen ueber die natürliche Familie der PolygonaceaeSt. Petersbourg (In der Buchdruckerei der kaiserlichen Akademie der Wissenschaften ). Reprinted from Mem. Acad. Imp. Sci. St. Petersbourg, Sci. math, 6(2):135-151.

Michelmore R. W., Paran I. \& Kessel R. V. 1991. Identification of markers linked to disease-resistance genes by bulked segregant analysis. A rapid method to detect markers in specific genomic regions by using segregating populations. Proc. Natl. Acad. Sci. , 88: 9828 - 9832 .

Musil A. F. 1948. Distinguishing the species of Brassica by their seeds. U. S. Agric. Misc. Pub. No. 643.

Nowicke J.W. \& Skvarla J. J. 1977. Pollen morphology and the relationship of the Plumbaginaceae, Polygonaceae and Primulaceae to the order Centrospermae. Smith - sonian Contr. Bot., 37:1-64.

Ortiz S. \& Paiva J.A.R. 1999. Taxonomic notes on Polygonaceae from southern tropical Africa. Bot. J. linn. Soc., 131(2):167-176. 
Praglowski J. \& Punt W. 1973. An elucidation of the microreticulate structure of the exine. - Grana 13:45-50.

Rivera S. M. \& lenton MS 1999. Wood anatomical and mechanical properties of five native Argentinian timbers. Quebracho, 7:72-78.

Roberty G. \& Vautier S. 1964. Les genres de polygonacees. Boissiera, 10:1-128.

Rossetto M., lucarotti F., Hopper S.D. \& Dixo K.W. 1997. DNA fingerprinting of Eucalyptus gramiticola, a critically endangered relict species or a rare hybrid. Herdity, 79:310-318.

Stearn W.T. 1966. Botanical Latin. Thomas LTd, London and Edinburgh.

Szmidt A.E., Wang X.R. \& Lu M.Z. 1996. Empirical assessment of allozyme and RAPD variation in Pinus sylvestris L. using haploid tissue analysis. Heredity, 6:412420.

Tantawy M.E. 1989. Morphological studies on the Polygonaceae. M. Sc. Thesis. Bot. Dept. Fac. Sci. Ain Shams Univ.

Tantawy M.E. 2000. Taxonomic significance of seed characters in some species of Rumex L. (Polygonaceae) with special reference to the seed coat sculpture. Egypt. $J$. Biotech. , 8:38-50.

Tantawy M.E. \& Rabie S.H. 2000. Scanning electron microscopic studies on seed coat of some species of Papaver L. (Papaveraceae). Egypt. J. Biotech., 8:28-37.

Virk P.S., Ford L.B.V., Jackson M.T. \& Newbury H.J. 1995. Use of RAPD for the study of diversity within plant germplasm collections. Heredity, 74:170-179.

Welsh J., Ralph D. \& Mc_Clelland M. 1995. DNA fingeprintirg using arbitrarily primer PCR. In: PCR Strategies (eds. Innis, M.A., David H.G. \& John J.S.). Academic Press, New York, USA, pp. $249-277$.

Wen C.Z. \& Hsiao J.Y. 1999. Genetic Differentiation of Lilium longiflorum Thumb. Bot. Bull. Acad. Sin., 40:65-71.

Wilkie S.E., Isaac P.G. \& Slater R.J. 1993. Random amplified polymorphic DNA (RAPD) markers for genetic analysis in Allium. Theor. Appl. Genet., 86:497-504.

Williams J.G.K., Kubelik A.R., Livak K.J., Rafalski J.A. \& Tingey S.V. 1990. DNA polymorphism amplified by arbitrary primers are useful genetic markers. Nucl. Acids Res., 18:6531-6535.Willians, J. G, Kanafey, M. K. , Rafalski, J. A. and Tirgey, S. V. (1993). Genetic analysis using random amplified polymorphic DNA markers. Methods Enzymol., 218:704-740.

Yang Y.W., Kuo W.H.J. \& Wong T.H. 1998. Genetic polymorphism of seven populations of Capsella bursa - pastoris based on RAPD markers. Bot. Bull. Acad. Sin., 39:17-21. 